\title{
Quantitative study on medicinal plants used for the treatment of respiratory diseases in chontales of Nacajuca, Tabasco, Mexico
}

\author{
Miguel Alberto Magaña Alejandro ${ }^{1,}{ }^{*}$, Merly Iveth Magaña Rodríguez ${ }^{2}$ and Manuel Sánchez Mendoza 3 \\ 1 Universidad Juárez Autónoma de Tabasco, Academic Division of Biological Sciences, Villahermosa, Centro, Tabasco \\ México. C.P. 86150. Tel office (993)3544308. Cell phone 9931113552. \\ 2 Universidad Juárez Autónoma de Tabasco. Medical Services Department, Villahermosa, Centro, Tabasco. \\ ${ }^{3}$ First Level Clinic Ciudad del Carmen, Campeche, Petróleos Mexicanos. Av. Constelación Pleyades S/N between Constelación \\ Dragón and Constelación Pegaso, Fracc., Santa Rita, Ciudad del Carmen, Campeche, Mexico.
}

Magna Scientia Advanced Biology and Pharmacy, 2021, 03(01), 019-026

Publication history: Received on 10 June 2021; revised on 18 July 2021; accepted on 20 July 2021

Article DOI: https://doi.org/10.30574/msabp.2021.3.1.0030

\begin{abstract}
The results of an evaluation of the traditional knowledge of the use of medicinal plants for the treatment of respiratory diseases among the inhabitants of five communities of Nacajuca, Tabasco, Mexico are presented. The study was conducted using ethnobotanical methods applied to 26 key informants. A total of 22 species used for respiratory diseases were recorded. Of the informants, $61.5 \%$ are traditional doctors, recognized by the people, the rest are people who only use them at home. Of these, the species that had the greatest relative importance due to their frequency of mention in the interviews were the Jícara (Crescentia cujete), the toad grass (Epaltes mexicana), the purple maguey (Tradescantia spathacea) and the elderberry (Sambucus mexicana). The part that they use the most are the leaves as tea. $77 \%$ grow them within their home gardens, others collect them in the field and only one buy them in the markets. Of the species reported for respiratory problems, most have other uses, being also ornamental, edible and timber. The greater participation of women is observed during the study, since they are the head of the family and have knowledge of the use of medicinal plants for lung diseases. This shows that traditional medicine continues to be of great importance for Chontal communities in solving respiratory problems.
\end{abstract}

Keywords: Chontales; Ethnobotany; Medicinal plants; Nacajuca; Respiratory diseases

\section{Introduction}

With the passage of time, the creation of cities, the penetration of different cultures and the advancement of science, the use of vegetables as medicine by a large number of inhabitants of Western countries was reduced, until just about three For decades, due to reasons such as the rising cost of patent medicines or the high cost of consultations by specialist doctors, the use of medicinal plants is back on the rise and popularity, especially in the so-called developed countries, who are beginning to make use of traditional methods. popular, homemade or the use of alternative therapeutic calls, for the treatment of diseases [1].

On the other hand, Mexico has a great wealth and ancestral tradition regarding the use of medicinal plants and it is estimated that currently about 3000 species are used for this purpose [2].

In this sense, one of the regions that deserves special attention due to its biocultural diversity is the Chontal route of Nacajuca, Tabasco. This constitutes a semi-flooded area located in the center of the state of Tabasco and is considered

\footnotetext{
${ }^{*}$ Corresponding author: Miguel Alberto Magaña Alejandro

Universidad Juárez Autónoma de Tabasco, Academic Division of Biological Sciences, Villahermosa, Centro, Tabasco México. C.P. 86150.
}

Copyright (C) 2021 Author(s) retain the copyright of this article. This article is published under the terms of the Creative Commons Attribution Liscense 4.0. 
one of the areas with the highest number of indigenous Chontales, despite the fact that it is a relatively small area, there are about 300 species of medicinal plants [3] and one of the four ethnic groups (Chontales, Tzotziles, Tzeltales and Choles) that still exist in Tabasco. Additionally, this region has had great importance for the reconstruction of the prehistory of the cultural region known as Mesoamerica.

In contrast to the studies carried out for Tabasco [4-8], few studies record ethnobotanical information. The available information mentions that the wealth of plant resources used by local human groups is very high. Thus, for example, in a recent study at the level of an entire municipality, [9] identified 460 species of vascular plants of which 60 are used as a remedy for the cure of different disease. In another more specific study, carried out in five communities in this region of the Chontal corridor [3], identified 232 medicinal species belonging to 185 genera and 58 families of vascular plants.

To make better use of this type of study, information is required on the plants used in the place and especially with regard to the relative importance of the species in the area, as well as the identification of patterns in terms of distribution. of knowledge. The collection, analysis and validation of this information for the area is relevant from the point of view of applied ethnobotany, as it may contribute significantly to the definition of strategies for the use and management of its resources.

That is why in order to carry out this research, the objective was to carry out a study on the traditional knowledge of the medicinal species that are used by the Chontales of Nacajuca, for the treatment of respiratory system conditions, as well as documenting their forms of use and analyze the distribution of traditional knowledge of medicinal flora among the population.

\subsection{Study area}

Nacajuca, is located in the Chontalpa region, is located in the north of the state, at $18^{\circ} 09^{\prime}$ north latitude and $93^{\circ} 01^{\prime}$ west longitude. It is bordered to the north by the municipality of Centla; to the east with Paraíso and Centro; to the south with the Center and to the west with Cunduacan and Jalpa de Méndez. The terrain is completely flat, lacking any elevation, this characteristic makes it one of the areas of Tabasco with the largest flooded area in the state. It has an altitude of 10 m.s.n.m.

This municipality, according to the National Institute of Statistics and Geography [10], has a total population of 87,105 inhabitants. The basic products are mainly: corn and beans, however cane (Cyperus canus J. Presl. \& C. Presl.) Is also sown in large quantities as raw material for their crafts and coffee, cocoa, sugar cane and pineapple. for selfconsumption, among others. Livestock activity is low, since most of the territory is flooded [11]. The precipitation regime is characterized by an annual average of $1,707.2 \mathrm{~mm}$ with a monthly maximum average of $735.8 \mathrm{~mm}$ in September and a monthly minimum of $63.9 \mathrm{~mm}$ in February [11].

Almost three-quarters of the Yokot'an population lives in the municipalities of Nacajuca and Centro, these municipalities concentrate $71.3 \%$ of the Chontal-speaking population of Tabasco. To a lesser extent, they also live in the municipalities of Centla and Macuspana, in which 13 and 10.4\% are concentrated, respectively. Finally, the rest of the Chontal-speaking population lives dispersed in other municipalities, such as Jonuta, Jalpa de Méndez and Cunduacán [12]. In the case of Nacajuca, the main communities with the greatest presence of indigenous Chontales are Tucta, Mazateupa, Tapotzingo, Guaytalpa, Tecoluta and Olcuatitán. The first five communities are part of the Yokot'an tourist corridor and it is where this research was focused (Figure 1).

Despite the inhospitable condition of this ecosystem for man, it is believed that since ancient times and during the development of pre-Columbian cultures, a source of food has been found in the swamp (mainly lizards, pejelagartos and turtles) and in the flora a great provision of raw materials that are used as fibers. For a long time, the irrational exploitation of these resources has affected this ecosystem to the point of putting the main species of the swamp fauna in danger of local extinction [11]. Today, agriculture is no longer the predominant activity for many Chontales, although to some extent it still contributes to the family economy. The manufacture of handicrafts (such as hats, mats, curtains and pottery) has been considerably reduced and in some places, it can be said that it has almost disappeared; in others, livestock has gained ground. Changes in the physical environment have reduced the fishing activity of some populations, given the scarcity of species that previously were abundant [13].

What has endured in this Chontal zone is the family garden that are traditional agroecosystems with an important root in indigenous and peasant cultures, both in temperate and tropical regions, but today this production system has survived and is better represented in the tropical areas. Hence, most of the research related to this type of tradition has been carried out in these parts of the planet: $[14,15,16]$, among others. 
When we talk about home gardens, we immediately imagine that there are medicinal plants, however these are the fundamental part, although they have different spaces where they reproduce plants according to their uses. This is related to ethnic groups generally who have a worldview of gardens and species with their uses.

For men the greatest importance lies in the area of fruit production, but for women the main areas are medicinal and ornamental plants [17].

In this sense, these places have served as a germplasm bank by preserving various varieties of edible fruits, ornamental plants and mainly medicinal ones.

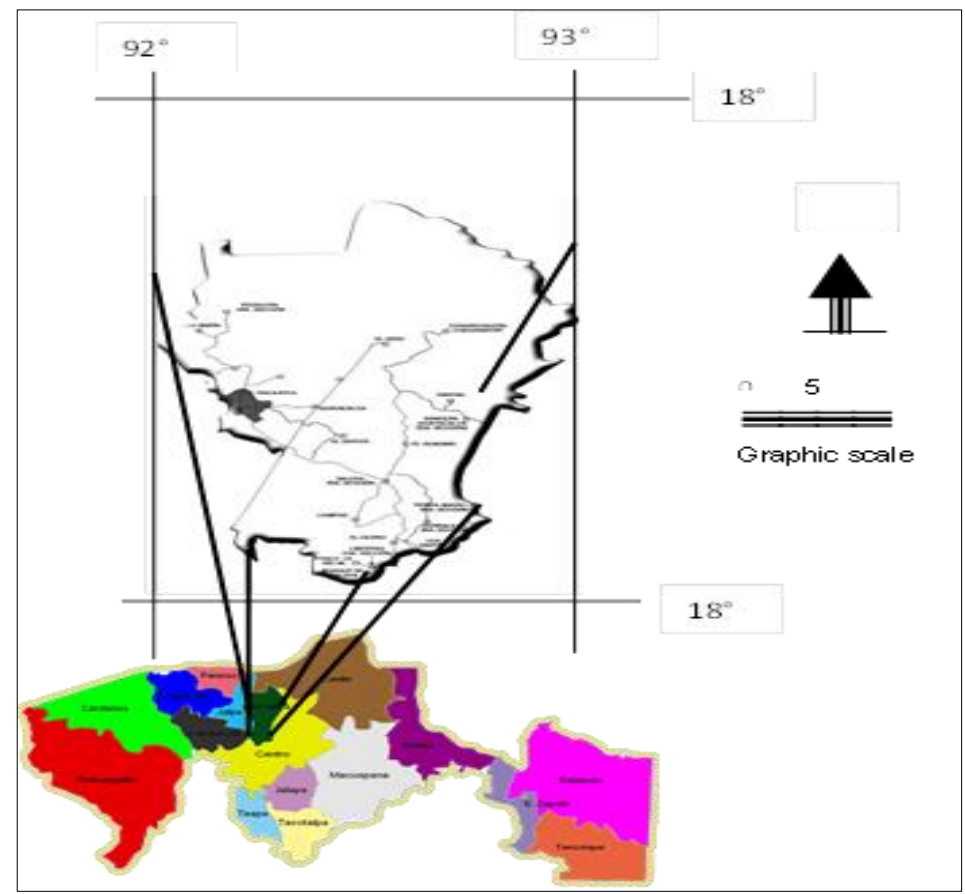

Figure 1 Location of the main study areas

\section{Material and methods}

An ethnobotanical methodology model was applied [18], which consists of obtaining the greatest amount of information from the population based on their active participation in the data collection stage.

Through this, one can closely observe the daily life of people, collecting all kinds of data that can shed light on the subject to be studied.

\subsection{Interviews}

Structured interviews were conducted with the informants, regardless of gender, generally following topics related to the use, knowledge, management, diseases that it cures, as well as the way in which knowledge of medicinal plants is acquired. The number of questionnaires that was applied per community depended on the information that was collected to find out who were the people who knew the most about plants and only one person from each house was considered. As there are healers in the communities, a way was sought to apply an unstructured interview to them, since they are the busiest people but also the ones who have the most knowledge about medicinal plants, which is why they are considered the town's doctors.

The inventory of medicinal plants used in the treatment of respiratory diseases and the evaluation of the relative importance of the species was done through semi-structured interviews [19], in addition, a list of recognized species was made, ranked according to the importance that each informant awarded him in curing respiratory diseases.

The interviews were applied to a sample of 26 individuals, who were chosen using the snowball technique [20] from a key informant. The sample included 14 men and 12 women, with people up to 80 years old, including traditional doctors. 
The important thing that women were found among the interviewees was that they are generally in charge of health care, while the inclusion of the elderly and traditional doctors allowed ensuring that a greater number of species were recognized [21].

\subsection{Collection and processing of simples}

Field trips were made to the locality, in which, based on the results of the interviews, the specimens mentioned as medicinal were collected, for this the collection technique proposed by Lot y Chiang [22], the which consists of collecting a representative sample of the plant, preferably those that are in the flowering and / or fruiting stage, for better identification. The collected material was deposited in the UJAT herbarium of the Academic Division of Biological Sciences.

In the same way, with the purpose of enriching the collection of plants in the medicinal botanical garden, some live specimens were collected from the Division of Biological Sciences, which were transported to the place where they were subsequently sown.

\subsection{Quantitative index}

To quantitatively determine the cultural importance or level of use that they give to medicinal plants, as well as the pattern of variation of traditional knowledge in the population, the following was done.

The relative importance of each species was calculated, which was obtained directly from the degree of consensus of the informants through the Friedman index (FL), which is calculated as FL $=$ (Ip / It) $\times 100$, where Ip: number of informants who mentioned a species (frequency of mention), and It: total number of informants.

\section{Results and discussion}

A total of 22 species belonging to 15 families and 20 genera were found used for the treatment of respiratory diseases. Of the species reported as medicinal for respiratory problems, most have different uses, thus 20 of them are used for the treatment of cough (sound and convulsive movement of the respiratory system), 15 for the treatment of the flu (disease caused by changes symptoms of which are mucus discharge, headache, chills and fever) 13 for the treatment of asthma (disorder that causes the airways to swell and narrow), nine for cold problems (runny nose, nasal congestion and sneezing that causes rhinorrhea) and only one is used for chichimeca (strong coughing fits accompanied by fever and choking) (Table 1).

Of the 22 species mentioned, six are wild, collected by people in the field, among which we find, Bactris balanoidea and Epaltes mexicana, 14 are cultivated in home gardens and gardens (Citrus aurantium, Cymbopogon citratus and Plecthranthus amboinicus) and only two buy it. in the markets [3].

It is well known that different parts of the plant are used for each species, the leaves being the most frequently used and the route of administration in all cases is oral, in the form of cooking. The way of preparation is in proportion a part of the plant for 20 parts of water. The plant and the water must be placed together until before boiling begins, it is extinguished to the fire and they are covered.

Table 1 Species used by the Chontales for respiratory diseases and relative importance of medicinal species

\begin{tabular}{|c|c|c|c|c|c|c|}
\hline Common name & $\mathbf{L}$ & Use & Species & Family & Ailment & FL \\
\hline Onion & CM & $\mathrm{T}, \mathrm{G}, \mathrm{A}, \mathrm{R}$ & Allium cepa L. & Alliaceae & Flu & 57.7 \\
\hline Jahuacte & $S$ & $\begin{array}{l}\mathrm{T}, \mathrm{G}, \mathrm{A}, \\
\mathrm{Ch}\end{array}$ & $\begin{array}{l}\text { Bactris balanoidea } \\
\text { (Oerst.) Wendl. }\end{array}$ & Arecaceae & $\begin{array}{l}\text { Asthma, } \\
\text { Bronchitis, } \\
\text { Cough }\end{array}$ & 38.4 \\
\hline Jocobal & $S$ & $\mathrm{~T}, \mathrm{R}$ & $\begin{array}{l}\text { Aristolochia } \\
\text { odoratissima L. }\end{array}$ & Aristolochiaceae & $\begin{array}{l}\text { Flu, Rhinitis, } \\
\text { Obstruction }\end{array}$ & 30.7 \\
\hline Toad grass & $\mathrm{S}$ & T, G & Epaltes mexicana Less & Asteraceae & $\begin{array}{l}\text { Flu, Cough, } \\
\text { Asthma, } \\
\text { Bronchitis }\end{array}$ & 69.2 \\
\hline Cuajilote & $\mathrm{HJ}$ & A, R & $\begin{array}{l}\text { Parmentiera aculeata } \\
\text { (Kunth) Seem. }\end{array}$ & Bignoniaceae & Otitis & 38.4 \\
\hline
\end{tabular}




\begin{tabular}{|c|c|c|c|c|c|c|}
\hline Jícara & $\mathrm{HJ}$ & $\mathrm{T}, \mathrm{G}, \mathrm{A}$ & Crescentia cujete L. & Bignoniaceae & $\begin{array}{l}\text { Asthma, } \\
\text { Bronchitis, } \\
\text { Cough }\end{array}$ & 73.1 \\
\hline Elder & $\mathrm{HJ}$ & $\mathrm{T}, \mathrm{G}, \mathrm{A}, \mathrm{R}$ & $\begin{array}{l}\text { Sambucus mexicana C. } \\
\text { Presl. ex DC. }\end{array}$ & Caprifoliaceae & $\begin{array}{l}\text { Asthma, } \\
\text { Bronchitis, Flu, } \\
\text { Sore throat, } \\
\text { Otitis } \\
\text { Hoarseness, } \\
\text { Cough }\end{array}$ & 57.7 \\
\hline Purple maguey & $\mathrm{HJ}$ & $\mathrm{T}, \mathrm{A}$ & $\begin{array}{l}\text { Tradescantia } \\
\text { spathacea Sw. }\end{array}$ & Commelinaceae & $\begin{array}{l}\text { Asthma, } \\
\text { Bronchitis, Flu, } \\
\text { Sore throat, } \\
\text { Rhinitis, Otitis, } \\
\text { Hoarseness, } \\
\text { Cough }\end{array}$ & 65.4 \\
\hline Squash & $\mathrm{HJ}$ & $\mathrm{G}, \mathrm{R}$ & $\begin{array}{l}\text { Sechium edule (Jacq.) } \\
\text { Sw. }\end{array}$ & Cucurbitaceae & Dry nose & 15.4 \\
\hline Cane fistula & $\mathrm{HJ}$ & $\mathrm{T}, \mathrm{A}$ & Senna fistula L. & Fabaceae & Cough, Flu & 42.3 \\
\hline Sleepyhead & S & $\mathrm{T}, \mathrm{R}$ & Mimosa pudica L. & Fabaceae & Throat pain & 23.1 \\
\hline Basil & $\mathrm{HJ}$ & $\mathrm{T}, \mathrm{G}$ & Ocimum basilicum L. & Lamiaceae & $\begin{array}{l}\text { Sore throat, } \\
\text { otitis }\end{array}$ & 15.4 \\
\hline Oreganon & $\mathrm{HJ}$ & $\mathrm{T}, \mathrm{G}, \mathrm{A}, \mathrm{R}$ & $\begin{array}{l}\text { Plecthranthus } \\
\text { amboinicus (Lour.) } \\
\text { Spreng }\end{array}$ & Lamiaceae & $\begin{array}{l}\text { Asthma, } \\
\text { Bronchitis, Flu, } \\
\text { Sore throat, } \\
\text { Otitis, } \\
\text { Hoarseness, } \\
\text { Cough }\end{array}$ & 46.1 \\
\hline Cinnamon & $\mathrm{CM}$ & $\mathrm{T}, \mathrm{G}, \mathrm{R}$ & $\begin{array}{l}\text { Cinnamomum } \\
\text { zeylanicum Breyne }\end{array}$ & Lauraceae & Flu, Rhinitis & 46.1 \\
\hline Bougainvillea & $\mathrm{HJ}$ & $\mathrm{T}, \mathrm{G}, \mathrm{A}$ & $\begin{array}{l}\text { Bougainvillea glabra } \\
\text { Choise }\end{array}$ & Nyctaginaceae & $\begin{array}{l}\text { Asthma, Cough, } \\
\text { Flu, Hoarseness }\end{array}$ & 34.6 \\
\hline Skunk & $\mathrm{S}$ & $\mathrm{T}, \mathrm{A}, \mathrm{R}$ & Petiveria alliacea L. & Phytolacaceae & Sinusitis & 53.8 \\
\hline Lemon grass & $\mathrm{HJ}$ & $\mathrm{T}, \mathrm{G}$ & $\begin{array}{l}\text { Cymbopogon citratus } \\
\text { Stapf. }\end{array}$ & Poaceae & $\begin{array}{l}\text { Flu, Sore throat, } \\
\text { Hoarseness, } \\
\text { Cough }\end{array}$ & 50.0 \\
\hline Bitter lemon & $\mathrm{HJ}$ & $\mathrm{T}, \mathrm{G}, \mathrm{A}$ & $\begin{array}{lll}\text { Citrus limon } & \text { (L.) } \\
\text { Burm. } & & \\
\end{array}$ & Rutaceae & $\begin{array}{l}\text { Flu, Cough, } \\
\text { Bronchitis, Sore } \\
\text { throat }\end{array}$ & 42.3 \\
\hline Bitter orange & $\mathrm{HJ}$ & $\mathrm{T}, \mathrm{G}$ & Citrus aurantium L. & Rutaceae & $\begin{array}{l}\text { Flu, Cough, Dry } \\
\text { nose, Blockage }\end{array}$ & 46.1 \\
\hline Sweet orange & $\mathrm{HJ}$ & $\mathrm{T}, \mathrm{G}$ & $\begin{array}{lll}\text { Citrus } & \text { sinensis } & \text { (L.) } \\
\text { Osb. } & & \\
\end{array}$ & Rutaceae & Flu, Cough & 42.3 \\
\hline Five little blacks & $S$ & $\mathrm{~T}, \mathrm{~A}$ & Lantana camara L. & Verbenaceae & $\begin{array}{l}\text { Rhinitis, } \\
\text { Obstruction }\end{array}$ & 30.8 \\
\hline Licorice & $\mathrm{HJ}$ & $\mathrm{T}, \mathrm{G}, \mathrm{A}$ & Lippia dulcis Trev. & Verbenaceae & $\begin{array}{l}\text { Asthma, } \\
\text { Bronchitis, } \\
\text { Hoarseness, } \\
\text { Cough }\end{array}$ & 65.4 \\
\hline
\end{tabular}

L: Place where they get it ( $\mathrm{S}=$ Wild, $\mathrm{CM}=$ Markets, $\mathrm{HJ}=$ Orchards and gardens). Use: $(\mathrm{T}=$ Cough, $\mathrm{G}=\mathrm{Flu}, \mathrm{A}=\mathrm{Asthma}, \mathrm{R}=\mathrm{Cold}, \mathrm{Ch}=\mathrm{Chichimeca})$.

The information recorded in table 1 shows that the Rutaceae family is the one with the highest number of species (3), which represents $13.6 \%$ of the total families used for the treatment of respiratory diseases; It is followed by the families Bignoniaceae, Fabaceae, Lamiaceae and Verbenaceae, all with two species, representing 9.1\%. 
Of the 26 interviews that were carried out, $100 \%$ of the informants use plants for the treatment of respiratory diseases, however, it is known that many people resort to the use of allopathic medicine.

Regarding the relative importance of the species, the results showed that the plants grown in the orchards obtained the highest values such as Crescentia cujete with a consensus of 73.1\%, followed by Lippia dulcis, Tradescantia spathacea and Sambucus mexicana. Among the wild plants that presented the highest values are: Epaltes mexicana 69.2\%, Petiveria alliacea with 53.8\% and Bactris balanoidea with 38.4\%.

Of the informants, $61.5 \%$ (16) are traditional doctors, that is, people who are recognized by the people and by themselves as connoisseurs of medicinal plants. This knowledge is reflected in the use and management they give them, since only the 16 traditional doctors contributed 95\% (21) of the total species. This is an expected result since specialists are more related to diseases and their treatments than non-specialists and therefore their knowledge is greater.

It is important to mention that there is a variation in relation to the gender of the informants. Thus, men mentioned an average of 10 medicinal species, while women reported 12 . These differences confirm that it is possible to say that it is women who recognize a greater number of plants with medicinal properties, but this is due to the fact that they are the ones who take more care of the sick and therefore the ones who use medicinal plants the most and also Those who consult more traditional doctors, on the other hand, men do not like any of these activities because they are dedicated to the field.

Regarding the distribution of knowledge in relation to age, figure 2 shows that the informants who are between 61 and 80 years old are the ones who recognize a greater number of species.

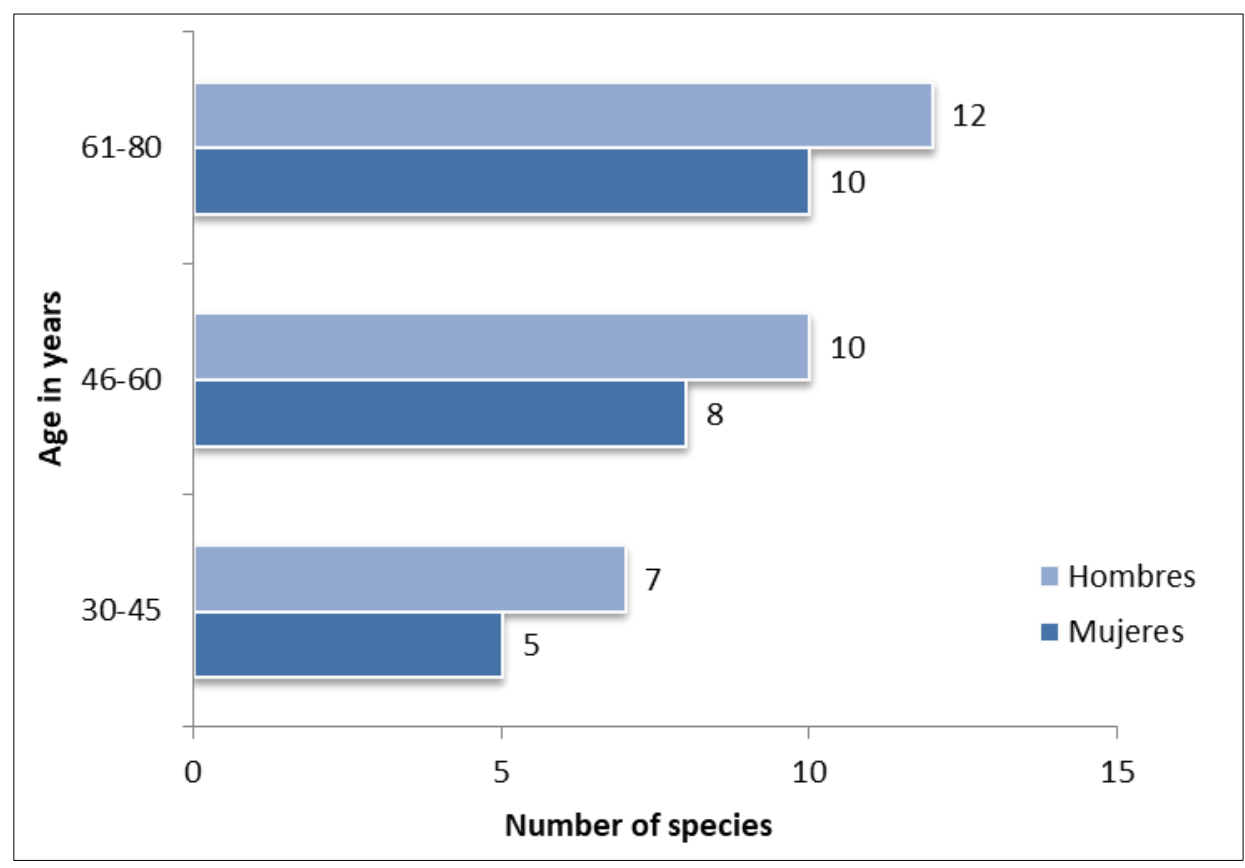

Figure 2 Species mentioned by informants according to gender and age (mean)

The results obtained agree with the research carried out by $[21,23]$, who mention that the knowledge of an individual is determined by the role they play in society (gender, age, division of labor, individual experience, etc.), thus generating variations in terms of access to knowledge. This confirms that, within the Chontales of Nacajuca, Tabasco, women have a greater knowledge of the species used in the treatment of respiratory diseases than men, due to the social role they play (care of the family) and that the older informants recognize a greater number of species (greater experience).

In this sense, research on medicinal plants continues to be notorious and the interest of many people in being cured with them has led different scholars and researchers to carry out studies in order to spread them, as did Méndez. Despite the fact that much of this knowledge is being lost, due to the little interest of young people to preserve this type of tradition and the impact of the oil activity that has caused a good number of them to migrate to other places [24]. According to Gallardo, cultures are in a constant process of change and transformation, given from the intrinsic 
evolution of each society and the adoption of new ideas and practices from the establishment of more or less close relationships with others. cultural manifestations [25].

\section{Conclusion}

Within the Chontales of Nacajuca, Tabasco, all the people interviewed resort to the use of medicinal plants for the treatment of respiratory conditions, among which are the flu and cough, asthma, chichimeca and cold.

As a result of the consensus analysis, Crescentia cujete, Lippia dulcis and Tradescantia spathacea turned out to be the most important cultivated species and Epaltes mexicana, Petiveria alliacea and Bactris balanoidea as wild plants for the cure of these disease.

Informants who are between 61 and 80 years old are those who recognize a greater number of medicinal species inheriting this knowledge from their parents.

In traditional Chontal medicine, magical elements and practices predominate, however, this medical practice is not the same in all communities, since some of them, because they are closer to the municipal seat, forget these magical elements and prefer allopathic medicine.

Traditional medical knowledge constitutes an important health alternative at any time in society, its procedures continue to be used and traditional medicine today constitutes an important possibility of recovering health based on the experiences of the patient himself.

\section{Compliance with ethical standards}

\section{Acknowledgments}

We are grateful to Mr. Apolonio de la Cruz as interpreter and to the traditional doctors of the communities studied for the information provided for this research.

\section{Disclosure of conflict of interest}

Authors have declared that no competing interests.

\section{Statement of ethical approval}

The present research work does not contain any studies performed on animals/human's subjects by any of the authors.

\section{Statement of informed consent}

Informed consent was obtained from all individual participants included in the study.

\section{References}

[1] Waizel BJ. Las plantas medicinales y las ciencias; una visión multidisciplinaria. a. ed. Instituto Politécnico Nacional. México. D.F. 2006; 587.

[2] Linares D, Bye R, Flores B. Plantas medicinales de México usos, remedios y tradiciones. Instituto de Biología. UNAM. México. 1999; 155.

[3] Magaña AMA. Conocimiento tradicional de las plantas medicinales en cinco comunidades Maya-Chontales del municipio de Nacajuca, Tabasco. Tesis doctoral. Universidad Juárez Autónoma de Tabasco. 2009; 378.

[4] Ramírez HSG. Las Acanthaceae de Tabasco y su potencial como plantas ornamentales. Tesis de licenciatura. Universidad Juárez Autónoma de Tabasco. 2005; 119.

[5] Jiménez AHL, Diversidad, uso y manejo de especies arbóreas en pastizales cultivados del poblado C-20 “Miguel Hidalgo y Costilla" Cárdenas, Tabasco. Tesis licenciatura. Universidad Juárez Autónoma de Tabasco. 2006; 119.

[6] De la Cruz LM. Inventario de plantas ornamentales de cinco comunidades del municipio de Nacajuca, Tabasco. Tesis licenciatura. Universidad Juárez Autónoma de Tabasco. 2007; 74. 
[7] Maldonado SEA. Estructura y diversidad arbórea de la selva alta perennifolia de la reserva ecológica "Yu-Balcah", Tacotalpa, Tabasco, México. Tesis licenciatura. Universidad Juárez Autónoma de Tabasco. 2007; 83.

[8] Cabrera PS. Usos y vulnerabilidad de la flora leñosa multiuso de niños héroes, Tenosique, Tabasco. Tesis maestría. Colegio de la Frontera Sur. 2011; 123.

[9] Magaña AMA. Vegetación y flora del municipio de Paraíso. Universidad Juárez Autónoma de Tabasco. 2010; 163.

[10] INEGI. Instituto Nacional de Estadística, Geografía e Informática. XIII Censo general de población y vivienda. 2005.

[11] INEGI. Instituto Nacional de Estadística, Geografía e Informática. XII Censo general de población y vivienda. 2000.

[12] Flores LJM. Chontales de Tabasco. Pueblos indígenas del México contemporáneo. Comisión nacional para el desarrollo de los pueblos indígenas. México, DF. 2006; 52.

[13] Cabrera H, y Hugo M. Cambio tecnológico en la agricultura maicera de un pueblo chontal de Tabasco, en América Indígena. 1994; LIV: 1-2.

[14] Allison JL. An ecological analysis of home gardens (huertos familiares) in two Mexican villages. M. A. Thesis Biology. Universidad de California. Sta. Cruz, USA. 1983; 129.

[15] Gispert M. Gómez A. y Núñez A. Concepto y manejo tradicional de los huertos familiares en dos bosques tropicales mexicanos. En: Cultura y manejo sustentable de los recursos naturales. Vol II. Coordinadores Enrique Leff y Julia Carabias. 1993; 575-623.

[16] Lamont SR. Eshbaugh WH. y Greenberg AM. Species composition diversity and use of home gardens among three Amazonian villages. Economic Botany. 1999; 53(3): 312-326.

[17] Jai VP, Paniagua N, y Morales R.M. Etnobotánica en los Andes de Bolivia. Botánica económica de los Andes centrales. 2006; 224-238.

[18] Martin GJ. Etnobotánica: Manual de métodos. Editorial Nordan- Comunidad. Montevideo, Uruguay. 2001; 239.

[19] Bernard HR. Research methods in anthropology: qualitative and quantitative approaches. Sage. Thousand Oaks. CA, EEUU. 1994; 203-224.

[20] Goodman LA. Muestreo en bola de nieve. Annals of Mathematical Statistics. Universidad de Chicago. 1961; 32 : 148 - 170.

[21] Boster JS. Requiem for the omniscient informant: there's life in the old girl yet. in Dougherty J. (ed.). Explorations in cognitive anthropology. University of Illinois Press. Urbana, IL., EEUU. 1986; 177-197.

[22] Lot A, y F Chiang. Manual de herbario: administración y manejo de colecciones, técnicas de recolección y preparación de ejemplares botánicos. Edit. Consejo Nacional de la Flora de México, S. A. de C. V. 1986.

[23] Garro LC. Intracultural variation in folk medical knowledge: a comparison between curers and non-curers. Am. Anthropol. 1986; 88: 351-369.

[24] Méndez OMS. Propagación por estacas de plantas medicinales utilizadas en la Villa Ocuiltzapotlan, Centro, Tabasco. Tesis. Profesional. Universidad Juárez Autónoma de Tabasco. D. A. C. Biol. Villahermosa, Tabasco México. 1999; 48.

[25] Gallardo RJ. Medicina Tradicional Purépecha. Instituto Michoacano de Cultura. 2002; 345. 